WHOI $-81-79$

\title{
MICROEARTHQUAKE ACTIVITY ON THE OROZCO FRACTURE ZONE: PRELIMINARY RESULTS FROM PROJECT ROSE
}

by

\author{
J.I. Ewing \\ and \\ G.M. Purdy \\ WOODS HOLE OCEANOGRAPHIC INSTITUTION \\ Woods Hole, Massachusetts 02543
}

September 1981

TECHNICAL REPORT

Prepared for the Office of Naval Research under Contract N00014-79-C-0071; NR 083-004.

Reproduction in whole or in part is permitted for any purpose of the United States Govemment. In citing this report in a bibliography the reference given should be to: Journal of Geophysical Research 86(B5): 3783-3790 (May 10, 1981).

Approved for public release; distribution unlimited. Approved for Distribution: John I. Ewing, Chairman Department of Geology and Geophysics 


\title{
Microearthquake Activity on the Orozco Fracture Zone: Preliminary Results From Project RosE
}

\author{
PROJECT ROSE SCIENTISTS ${ }^{1}$
}

\begin{abstract}
We present preliminary hypocenter determinations for 52 earthquakes recorded by a large multiinstitutional network of ocean bottom seismometers and ocean bottom hydrophones in the Orozco Fracture Zone in the eastern Pacific during late February to mid-March 1979. The neework was deployed as part of the Rivera Ocean Seismic Experiment, also known as Project ROSE. The Orozco Fracture Zone is physiographically complex, and the pattern of microearthquake hypocenters at least partly reflects this complexity. All of the well-located epicenters lie within the active transform fault segment of the fracture zone. About half of the recorded earthquakes were aligned along a narrow trough that extends eastward from the northern rise crest intersection in the approximate direction of the Cocos-Pacific relative plate motion; these events appear to be characterized by strike-slip faulting. The second major group of activity occurred in the central portion of the transform fault; the microearthquakes in this group do not display a preferred alignment parallel to the direction of spreading, and several are not obviously associated with distinct topographic features. Hypocentral depth was well resolved for many of the earthquakes reported here. Nominal depths range from 0 to $17 \mathrm{~km}$ below the seafloor.
\end{abstract}

\section{INTRODUCTION}

The Rivera Ocean Seismic Experiment (ROSE) is a multiinstitutional study of the structural evolution of young oceanic crust and mantle and of the structure and tectonics of an active transform fault [Wilson, 1965] using a large network of ocean bottom seismometers (OBS) and ocean bottom hydrophones (OBH) [Ewing, 1979]. The field work for Project ROSE consisted of two phases during January to March 1979. In Phase I a number of seismic refraction lines were shot both parallel and perpendicular to isochrons on 0 - to 4-m.y.-old seafloor near the East Pacific Rise at $11^{\circ}$ to $13^{\circ} \mathrm{N}$ latitude. Phase II consisted of a predominantly passive survey of microearthquake activity on the Orozco transform fault and adjacent rise axis areas. Groups from 12 institutions, including the University of California at San Diego and at Santa Barbara, University of Hawaii, Instituto Oceanográphico at Manzanillo, Lamont-Doherty Geological Observatory, Massachusetts Institute of Technology (MIT), Naval Ocean Research and Development Activity, Naval Research Laboratory, Oregon State University, University of Texas, University of Washington, and Woods Hole Oceanographic Institution (WHOI), participated in the field work, conducted from five research vessels (R/V Robert Conrad, R/V Kana Keoki, R/V

\footnotetext{
'Project ROSE scientists providing data for this study include J. I. Ewing and G. M. Purdy at the Department of Geology and Geophysics, Woods Hole Oceanographic Institution, Woods Hole, Massachusetts 02543; A. M. Tréhu and S. C. Solomon at the Department of Earth and Planetary Sciences, Massachusetts Institute of Technology, Cambridge, Massachusetts 02139; T. Ouchi and A. K. Ibrahim at the Marine Science Institute, University of Texas, Galveston, Texas 77550 ; J. F. Gettrust and K. Furukawa at the Hawaii Institute of Geophysics, University of Hawaii, Honolulu, Hawaii 96822; S. P. Nishenko and P. W. Pomeroy at Lamont-Doherty Geological Observatory, Columbia University, Palisades, New York 10964; W. A. Prothero at the Department of Geological Sciences, University of California at Santa Barbara, Santa Barbara, California 93106; J. D. Garmany and B. T. R. Lewis at the Department of Oceanography, University of Washington, Seattle, Washington 98195; and S. H Johnson and L. D. Bibee at the School of Oceanography, Oregon State University, Corvallis, Oregon 97331. Epicenter locations were calculated by A. M. Tréhu.
}

Copyright (C) 1981 by the American Geophysical Union.
Thomas Thompson, USNS De Steiguer, USNS Hayes). A total of 67 ocean bottom seismometers and hydrophones as well as several hydrophone arrays were deployed, and several multichannel seismic lines were also run. This paper presents the preliminary locations of the largest microearthquakes recorded by the OBS and овH array in the Orozco Fracture Zone during phase II of ROSE.

The Orozco transform fault, at approximately $15.25^{\circ} \mathrm{N}$ latitude, offsets the East Pacific Rise left laterally by about $90 \mathrm{~km}$ (Figure 1). The local spreading rate is $49 \mathrm{~mm} / \mathrm{yr}$ (half-rate) with an azimuth of $\mathrm{N} 85^{\circ} \mathrm{E}$, based on the Cocos-Pacific pole of Minster and Jordan [1978]. Thus the maximum age contrast across the transform is about $2 \mathrm{~m}$.y. at present. The large-scale topographic manifestation of the Orozco Fracture Zone (Figure 1) belies this modest offset and is a reflection of a past tectonic configuration. The complicated bathymetry to the west of the current spreading center has been interpreted to contain the signature of a number of eastward jumps of the spreading center [Sclater et al., 1971; Lynn and Lewis, 1976]. Before a proposed jump 4-5 m.y. ago, the Orozco Fracture Zone may have marked the boundary between the Rivera and Pacific plates, a role currently played by the Rivera Fracture Zone [Klitgord and Mammerickx, 1979].

A number of microearthquake surveys in oceanic transform fault and ridge crest areas have been conducted with sonobuoys and with ocean bottom seismometers [Francis and Porter, 1973; Reid et al., 1973, 1977; Reid and Macdonald, 1973; Spindel et al., 1974; Macdonald and Mudie, 1974; Prothero et al., 1976; Reichle et al., 1976; Reichle and Reid, 1977; Solomon et al., 1977; Francis et al., 1977, 1978; Lilwall et al., 1977, 1978; Johnson and Jones, 1978; Jones and Johnson, 1978]. Because all such previous studies have been conducted with at most a few stations, the epicentral location capabilities have been quite limited, and the focal depth resolution generally poor. Thus the detailed relationship between epicenter locations and specific physiographic features has often been suspect, and the important information from focal depths on deep thermal and mechanical structure has typically been absent in such surveys. Project ROSE is unprecedented in the large number of ocean bottom stations deployed in concert for a dedicated experiment of oceanic earthquake characterization. Because of the large OBS and OBH network the epi- 


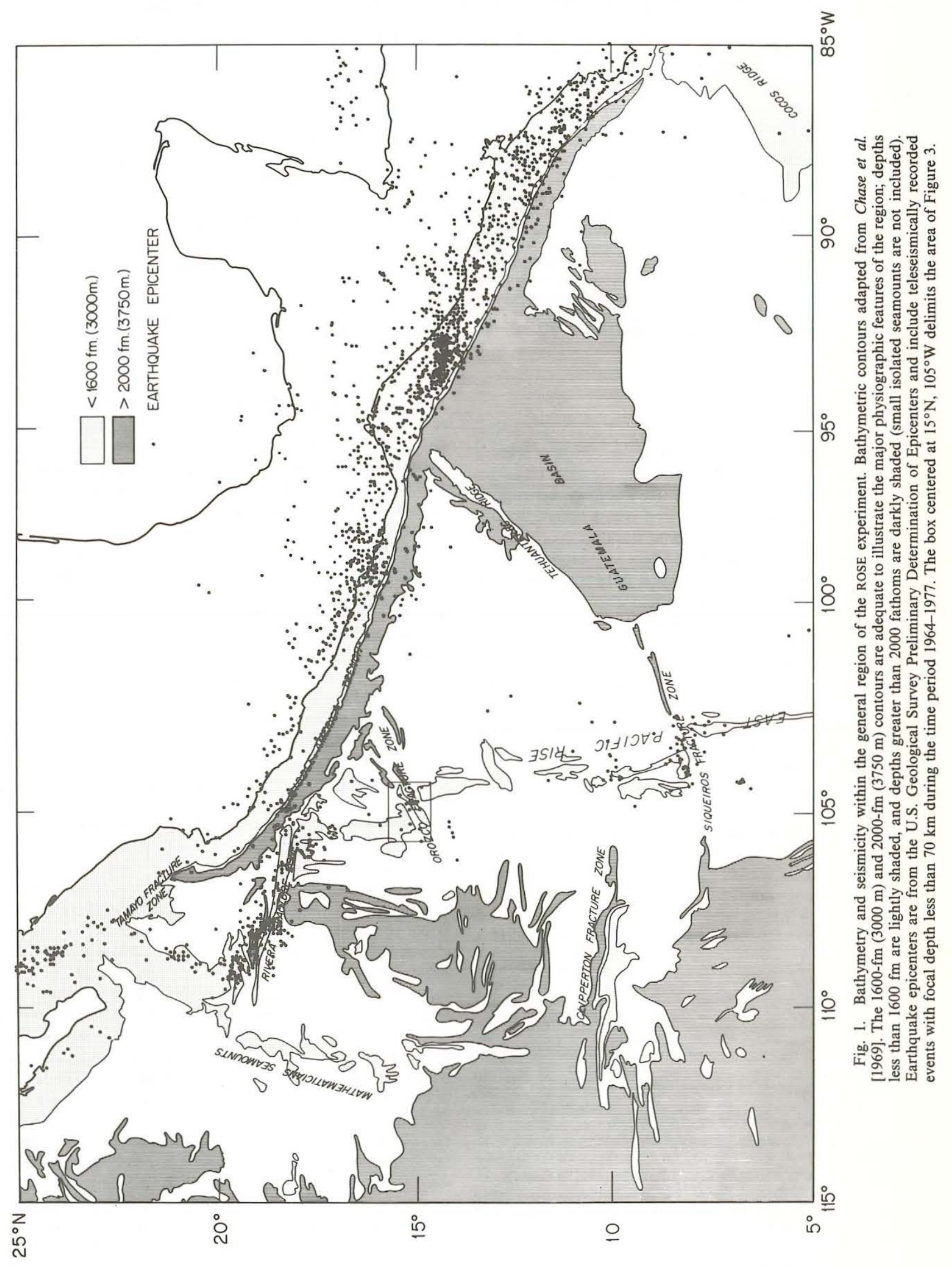


central locations, focal depths, and other source parameters of the earthquakes recorded during ROSE phase II are unusually well constrained.

Fifty-two earthquakes which occurred during the 2-week period from February 27 to March 13 have been located using arrival times from the OBS and OBH network during the second phase of ROSE. All of the well-located events are within what one would expect to be the active portion of the transform, and many are clearly associated with topographic features. More detailed analysis of our data and discussions of the tectonic significance of our findings will be presented in later publications.

\section{DATA}

Data from 26 instruments belonging to 8 institutions were used for the locations. The important features of these instruments and their geographic coordinates during deployment are summarized in Tables $1 a$ and $1 b$. This data set represents approximately two thirds of the instruments operating during the second phase of the ROSE project. Figure 2 shows histograms of the number of events per 12-hour period observed by these instruments. $P$-wave arrival time readings were obtained from all stations; $S$-wave arrival times could only be picked to the desired accuracy from those stations equipped with two horizontal components.

Depth corrections were calculated to normalize all stations to a water depth of $3000 \mathrm{~m}$. A $P$-wave velocity of $6.5 \mathrm{~km} / \mathrm{s}$ was assumed in making this correction, and $S$-wave arrival times were corrected by assuming a ratio of $P$-wave to $S$-wave velocity of 1.75 . All times were also corrected for clock drift assuming a constant drift rate during the time of deployment. Total clock drift over a period of a month was on the order of 0.25 seconds for most instruments.

Reading errors in picking the arrival times were less than $0.04 \mathrm{~s}$ for most of the events and most of the instruments. Possible nonsteady clock drift and errors in the instrument location, however, increase the effective arrival time errors to about $0.08 \mathrm{~s}$ when the whole network is considered.

\section{LOCATION METHOD}

Earthquakes were located using the computer program HYPOINVERSE developed by the U.S. Geological Survey [Klein, 1978]. The nonlinear nature of the earthquake location problem is well known, as is its linear approximation in the form $[A] \cdot[x]=[b]$, where $[A]$ is an $n \times 4$ matrix of the travel time derivatives, $[x]$ is a 4-dimensional vector of adjustments to an assumed hypocenter and origin time, and $[b]$ is an $n$-dimensional vector of differences between the observed arrival times and those calculated for the assumed hypocenter. Because HYPOINVERSE solves for $[x]$ by doing a singular value decomposition on $[A]$ and calculating the generalized inverse of $[A]$, the method provides the resolution, covariance and data importance matrices. Moreover, by explicitly calculating the singular values and singular vectors of $[A]$, the method points out small singular values representing directions in which the hypocentral adjustment vector is poorly constrained by the data. The capacity to truncate small singular values and to damp adjustments in such directions increases the stability of the inversion. A reading error of 0.08 was assumed for the calculation of the covariance matrix.

Another important feature of the location algorithm is that it assigns weights to the observed arrival times as a function of

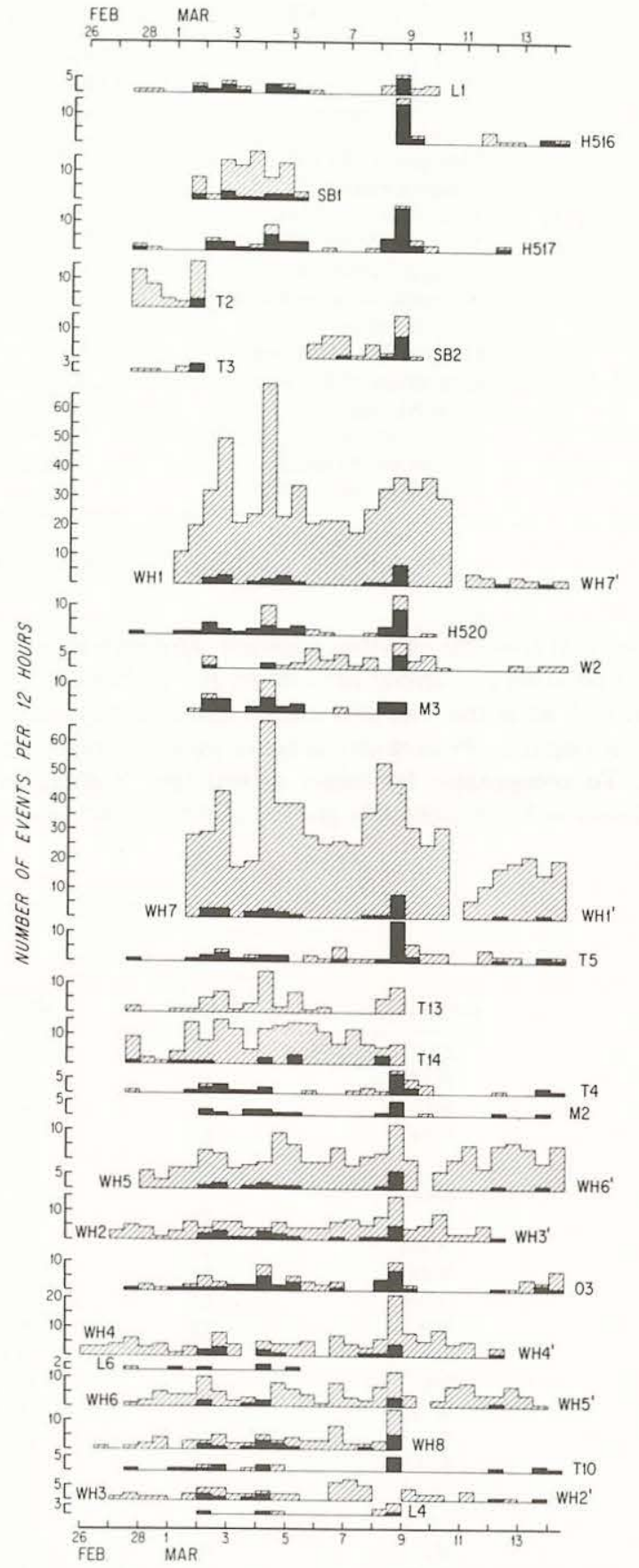

Fig. 2. Histograms of earthquake activity per half day observed during phase II of ROSE. The instrument identification codes are given in Table 1. Histograms for all instruments providing readings for this study are included and are stacked from top to bottom in order of decreasing latitude. The hatched area represents all events reported for the instrument, whereas the solid area represents only those earthquakes located in this study and listed in Table 3. No arrival times from T13 were used for the locations. The great number of events reported from the WHOI instruments is partly an artifact of the method of defining an 'event.' For the continuously recording WHOI instruments, any discrete event with a maximum amplitude of at least twice the background noise level was defined as an event; for many of these it is impossible to pick a first arrival. For the other instruments, only those events whose arrival time had been determined were included. Note also that instruments SB1, SB2, T2, and T14 recorded many, presumably very nearby events which were not recorded by enough instruments to permit a location to be calculated. 
TABLE 1a. Characteristics of Ocean Bottom Seismometers and Hydrophones Used for This Study

\begin{tabular}{|c|c|c|c|c|}
\hline Institution & $\begin{array}{l}\text { Institution } \\
\text { Abbrevia- } \\
\text { tion }\end{array}$ & Components* & Recording $\dagger$ & Reference \\
\hline $\begin{array}{l}\text { University of California at } \\
\text { Santa Barbara }\end{array}$ & SB & $\mathrm{V}, \mathrm{H}, \mathrm{H}$ & $\mathrm{D}, \mathrm{E}$ & Prothero [1979] \\
\hline University of Hawaii & $\mathrm{H}$ & $\mathrm{V}, \mathrm{H}, \mathrm{P}$ & $\mathrm{A}, \mathrm{C}$ & Sutton et al. [1977] \\
\hline $\begin{array}{l}\text { Lamont-Doherty Geo- } \\
\text { logical Observatory }\end{array}$ & L & $\mathrm{V}, \mathrm{P}$ & $\mathrm{A}, \mathrm{C}$ & Bookbinder et al. [1978] \\
\hline $\begin{array}{l}\text { Massachusetts Institute of } \\
\text { Technology }\end{array}$ & M & $\mathrm{V}, \mathrm{H}, \mathrm{H}$ & $\mathrm{D}, \mathrm{E}$ & $\begin{array}{l}\text { Mattaboni and Solomon } \\
\text { [1977] }\end{array}$ \\
\hline Oregon State University & 0 & $\mathrm{~V}, \mathrm{P}$ & $\mathrm{A}, \mathrm{C}$ & S. H. Johnson et al. [1977] \\
\hline $\begin{array}{l}\text { University of Texas at } \\
\text { Galveston }\end{array}$ & $\mathrm{T}$ & V & $\mathrm{A}, \mathrm{E}$ & Latham et al. [1978] \\
\hline University of Washington & W & V, H, H & $\mathrm{A}, \mathrm{C}$ & R. V. Johnson et al. [1977] \\
\hline $\begin{array}{l}\text { Woods Hole Oceano- } \\
\text { graphic Institution }\end{array}$ & WH & $\mathrm{P}$ & $\mathrm{A}, \mathrm{C}$ & Koelsch and Purdy [1979] \\
\hline
\end{tabular}

the residual from the previous iteration. This provision is useful for pointing out arrival time readings which are grossly in error, such as in the case of a misidentification of phase. For the first iteration, $P$-wave arrival times were assigned a weight of 1 . To compensate for larger arrival time reading errors combined with the inherently greater importance of these read- ings toward the solution, $S$-wave arrival times were weighted by a factor of 0.75 . A complete description of the location program is given by Klein [1978].

The assumption that $[A]$ is known implies that the velocity structure is known. We assumed that the $P$-wave velocity structure was a stack of 9 homogeneous, flat layers approxi-

TABLE $1 b$. Geographic Coordinates of Instruments During Phase II of RosE

\begin{tabular}{|c|c|c|c|c|c|}
\hline \multirow[b]{2}{*}{ Instrument } & \multicolumn{2}{|c|}{ Latitude } & \multicolumn{2}{|c|}{ Longitude } & \multirow{2}{*}{$\begin{array}{c}\text { Depth } \\
\text { (Corrected } \\
\text { Meters) }\end{array}$} \\
\hline & Degrees & Minutes & Degrees & Minutes & \\
\hline L1 & 15 & 30.30 & 105 & 25.98 & 2800 \\
\hline H516 & 15 & 29.60 & 105 & 5.30 & 2842 \\
\hline SB1 & 15 & 26.20 & 105 & 4.40 & 2801 \\
\hline H517 & 15 & 25.40 & 104 & 56.60 & 3883 \\
\hline $\mathrm{T} 2$ & 15 & 25.20 & 105 & 15.10 & 3010 \\
\hline SB2 & 15 & 21.70 & 105 & 2.00 & 3032 \\
\hline T3 & 15 & 18.16 & 105 & 12.76 & 3041 \\
\hline WH1 & 15 & 13.98 & 104 & 54.72 & 2678 \\
\hline WH7 $7^{\prime}$ & 15 & 13.98 & 104 & 54.48 & 2740 \\
\hline H520 & 15 & 12.70 & 104 & 55.10 & 2725 \\
\hline W2 & 15 & 10.50 & 105 & 18.50 & 3388 \\
\hline M3 & 15 & 9.30 & 104 & 55.32 & 2855 \\
\hline WH7 & 15 & 9.18 & 104 & 50.58 & 2863 \\
\hline WH1' & 15 & 9.12 & 104 & 52.38 & 2890 \\
\hline T5 & 15 & 8.70 & 105 & 11.30 & 3572 \\
\hline T13 & 15 & 6.92 & 104 & 38.73 & 3214 \\
\hline T14 & 15 & 6.67 & 104 & 31.27 & 2791 \\
\hline T4 & 15 & 6.10 & 105 & 27.10 & 3090 \\
\hline M2 & 15 & 5.58 & 104 & 56.22 & 2856 \\
\hline WH6' & 15 & 3.42 & 104 & 45.18 & 2203 \\
\hline WH5 & 15 & 1.98 & 104 & 44.88 & 2517 \\
\hline WH3' & 14 & 59.88 & 105 & 16.50 & 3013 \\
\hline WH2 & 14 & 59.10 & 105 & 16.98 & 2996 \\
\hline $\mathrm{O} 3$ & 14 & 58.43 & 104 & 50.14 & 4068 \\
\hline WH4 & 14 & 54.90 & 105 & 8.52 & 3098 \\
\hline WH4' & 14 & 53.82 & 105 & 8.01 & 3090 \\
\hline L6 & 14 & 52.38 & 104 & 30.00 & 2966 \\
\hline WH $5^{\prime}$ & 14 & 51.00 & 104 & 44.40 & 2678 \\
\hline WH6 & 14 & 50.52 & 104 & 44.40 & 2715 \\
\hline WH8 & 14 & 49.68 & 105 & 22.62 & 3184 \\
\hline $\mathrm{T} 10$ & 14 & 48.43 & 104 & 59.43 & 3347 \\
\hline WH $2^{\prime}$ & 14 & 40.80 & 105 & 15.00 & 3311 \\
\hline WH3 & 14 & 40.38 & 105 & 15.72 & 3329 \\
\hline L4 & 14 & 31.32 & 105 & 15.35 & 3203 \\
\hline
\end{tabular}

In the instrument identifications the letters refer to the institution abbreviations of Table $1 a$, and the numbers to each institution's numbering scheme. The 'primed' WHOI identifications correspond to the position of each instrument after being redeployed. Because the tape capacity of the WHOI instruments is about 8 days, most were retrieved and redeployed midway through phase II. 
mating a two-layer crust with velocity gradients in each layer (Table 2). This structure was based on the results obtained from line B of Orcutt et al. [1976] and line 57 of Lewis and Snydsman [1979], refraction profiles shot parallel to the spreading center to the south of the ROSE study area at $9^{\circ} \mathrm{N}$ and $13.5^{\circ} \mathrm{N}$ on crust with ages of 2.9 and 0.4 m.y., respectively. The $S$-wave velocity model was obtained from the $P$ wave model assuming a $P$-wave to $S$-wave velocity ratio of 1.75 .

\section{EARTHQUAKE LOCATIONS}

The hypocentral parameters of the earthquakes located during phase II of ROSE are presented in Table 3. All events located with a root-mean-squared residual of less than $0.25 \mathrm{~s}$ are included. Although data from 26 stations were used, no event was recorded by all stations. Thirteen earthquakes were located using at least 15 arrival time readings. Most locations calculated from only four or five readings are supported by temporal and spatial association with a larger, well-located earthquake and by a $P-S$ arrival time interval in agreement with that measured on the MIT instruments. An initial hypocenter close to the station reporting the earliest arrival was assumed. The locations were calculated twice, starting from initial depths of 5 and $12 \mathrm{~km}$. For most events the two initial hypocenters converged to the same solution. For a few events, however, two different depths were obtained. An examination of the behavior of the root-mean-squared residual with depth when locations were calculated for a series of fixed depths from 2 to $20 \mathrm{~km}$ indicated that this behavior could be attributed to a constant residual with depth over an interval around one of the initial depths. In these cases the solution giving the smaller residual was chosen; with the exception of four events (March 2, 1300 hours; March 2, 1721 hours; March 3, 1724 hours; March 4, 2010 hours) this was the shallower solution.

The axes of the covariance matrix of the hypocentral solution define the $32 \%$ confidence ellipse of the solution to the linearized problem. The $95 \%$ confidence ellipse can be obtained by multiplying the axis lengths by 2.4 . Because the problem is not linear, these ellipses provide only a qualitative measure of the precision of the location. The projections of these axes onto horizontal and vertical planes through the hypocenter are listed in Table 3 as measures of the horizontal and vertical errors in the solution. Only the larger of the two horizontal errors is listed. These formal errors suggest that most of the earthquake locations are precise to within 1 or $2 \mathrm{~km}$ in the horizontal direction and point out those events for which the

TABLE 2. Layered $P$-Wave Velocity Model Used for Earthquake Locations

\begin{tabular}{cccc}
\hline Layer & $\begin{array}{c}\text { Velocity, } \\
\mathrm{km} / \mathrm{s}\end{array}$ & $\begin{array}{c}\text { Depth, } \\
\mathrm{km}\end{array}$ & $\begin{array}{c}\text { Thickness, } \\
\mathrm{km}\end{array}$ \\
\hline 1 & 4.38 & 0.00 & 0.40 \\
2 & 5.00 & 0.40 & 0.40 \\
3 & 5.62 & 0.80 & 0.40 \\
4 & 6.05 & 1.20 & 0.80 \\
5 & 6.39 & 2.00 & 1.00 \\
6 & 6.73 & 3.00 & 1.00 \\
7 & 7.07 & 4.00 & 1.00 \\
8 & 7.42 & 5.00 & 1.00 \\
9 & 7.72 & 6.00 & 0.65 \\
10 & 7.84 & 6.65 & \\
\hline
\end{tabular}

geometry of the available data provides little constraint on the hypocentral depth.

Locating events with other layered crustal models or with different subsets of the data did not change the absolute or relative locations significantly. For example, substitution of the 'average oceanic crust' of Raitt [1963] resulted in a change in the calculated hypocenter of less than $1 \mathrm{~km}$ horizontally and less than $2 \mathrm{~km}$ vertically for most events.

Although most of the earthquakes were not detected by all of the instruments, the large number of instruments deployed during ROSE was useful for two reasons. It obviously extended the spatial extent of the area of good hypocentral resolving power of the network compared to the much smaller networks of instruments used in earlier studies. Equally importantly, however, the large number of stations led to the detection of errors in data processing which might otherwise have been undetected and would have therefore led to erroneous locations. An examination of the residuals at each station for those events located using 18 or more arrivals revealed systematic trends which could be traced to errors in the clock drift correction for a few instruments. Small events located using only 4-6 arrival times including these erroneous data often seemed to be well located (as indicated by small root-meansquared residuals and covariance ellipses) when actually their locations were in error by several kilometers.

The calculated epicenters are superimposed on a map of the local bathymetry in Figure 3. The bathymetric map includes data obtained during Project ROSE and indicates a complex tectonic environment. The transform fault is marked by a $90-$ $\mathrm{km}^{2}$ area of dramatic topography. Most of the earthquake activity was localized in two areas and is visibly related to topographic features.

About one half of the earthquakes located occurred in the northwestern portion of the transform area and were aligned along a long, narrow trough with a strike of $\mathrm{N} 80^{\circ} \mathrm{E}$. That this trend probably represents the current spreading direction is supported by the predicted Cocos-Pacific spreading direction [Minster and Jordan, 1978], by nearby magnetic anomalies [Klitgord and Mammerickx, 1979], by a teleseismic study of a large $\left(m_{b}=5.1\right)$ event from the transform (A. M. Tréhu, work in progress, 1981), and by the trend of anisotropy beneath a possible low-velocity zone in the upper mantle (G. M. Purdy, work in progress, 1981). During the period of the experiment, activity was distributed along the length of the trough. During March 1-4, activity occurred at the eastern and western extremities of the trough. Following a period of quiet during March 5-7, a main shock-aftershock sequence occurred near the center of the trough on the afternoon of March 8.

These events seem to have occurred over a broad range of depths. The calculated locations of many of the events from the westernmost end of the trough indicate a source in the upper mantle, whereas the events of the March 8 sequence seem to have been very shallow, within the upper crust. This interpretation is supported by the observation on the seismograms obtained by the MIT instruments of what is interpreted to be a mantle refraction as the first arrival from the largest events of March 8. This phase cannot be observed from the events at the westernmost end of the trough. Confirmation of these depth determinations will require a reexamination of the records in an attempt to identify characteristics diagnostic of the source depth. The calculated depths might also be a consequence of the simple layered velocity model. The polarity of the first motion observed on the MIT, WHOI, Lamont, Ha- 
TABLE 3. Hypocentral Parameters of Earthquakes Recorded During the Second Phase of RosE

\begin{tabular}{|c|c|c|c|c|c|c|c|c|c|c|c|c|c|}
\hline \multicolumn{2}{|c|}{ Orgin Time } & \multicolumn{2}{|c|}{ Latitude } & \multicolumn{2}{|c|}{ Longitude } & \multirow{2}{*}{$\begin{array}{c}\text { Depth, } \\
\text { km }\end{array}$} & \multicolumn{2}{|c|}{ nor } & \multirow{2}{*}{$\begin{array}{c}\mathrm{mag}, \\
\mathrm{deg}\end{array}$} & \multirow{2}{*}{$\begin{array}{l}\mathrm{dcs} \\
\mathrm{km}\end{array}$} & \multirow{2}{*}{$\begin{array}{c}\mathrm{rmsr}, \\
\mathrm{s}\end{array}$} & \multirow{2}{*}{$\begin{array}{l}\text { erh, } \\
\mathrm{km}\end{array}$} & \multirow{2}{*}{$\begin{array}{l}\text { erd, } \\
\mathrm{km}\end{array}$} \\
\hline Date 1979 & UT & Degrees & Minutes & Degrees & Minutes & & $P$ & $S$ & & & & & \\
\hline Feb. 27 & $2238: 36.31$ & 15 & 13.17 & 104 & 47.71 & 0.85 & 7 & 0 & 147 & 13.3 & 0.24 & 1.3 & 4.5 \\
\hline March 1 & $1150: 7.12$ & 15 & 4.68 & 104 & 38.14 & 3.56 & 4 & 2 & 191 & 12.8 & 0.07 & 0.8 & pdc \\
\hline March 1 & $1216: 23.12$ & 15 & 21.54 & 105 & 17.84 & 5.20 & 2 & 3 & 271 & 8.3 & 0.02 & 0.8 & 1.2 \\
\hline March 1 & $1457: 51.17$ & 15 & 22.52 & 105 & 14.40 & 0.10 & 6 & 2 & 90 & 5.1 & 0.19 & 0.7 & 2.0 \\
\hline March 1 & $1506: 34.58$ & 15 & 23.14 & 105 & 13.79 & 8.52 & 3 & 2 & 199 & 4.4 & 0.01 & 2.2 & 0.8 \\
\hline March 2 & $0523: 10.70$ & 15 & 14.97 & 104 & 44.13 & 11.47 & 19 & 2 & 218 & 15.8 & 0.14 & 1.0 & 1.7 \\
\hline March 2 & $0718: 4.85$ & 15 & 24.90 & 104 & 57.76 & 3.00 & 13 & 2 & 144 & 2.2 & 0.08 & 1.1 & 1.1 \\
\hline March 2 & $0854: 5.74$ & 15 & 6.88 & 104 & 49.14 & 10.04 & 3 & 1 & 323 & 4.9 & 0.00 & 2.4 & 1.4 \\
\hline March 2 & $1300: 20.92$ & 15 & 24.18 & 105 & 12.82 & 17.05 & 13 & 2 & 140 & 15.5 & 0.09 & 0.5 & 1.5 \\
\hline March 2 & $1335: 1.57$ & 15 & 6.47 & 104 & 49.22 & 10.15 & 3 & 1 & 322 & 5.5 & 0.00 & 2.6 & 1.5 \\
\hline March 2 & $1645: 8.41$ & 15 & 23.38 & 105 & 12.40 & 0.00 & 8 & 1 & 131 & 15.2 & 0.12 & 0.5 & 1.4 \\
\hline March 2 & $1721: 9.48$ & 15 & 24.24 & 105 & 11.96 & 14.18 & 15 & 2 & 139 & 14.0 & 0.09 & 0.5 & 2.2 \\
\hline March 3 & $1724: 58.03$ & 15 & 24.72 & 105 & 13.16 & 12.48 & 16 & 2 & 224 & 15.9 & 0.09 & 0.7 & 2.5 \\
\hline March 3 & $2311: 59.89$ & 15 & 10.94 & 104 & 49.17 & 5.22 & 4 & 2 & 290 & 4.1 & 0.12 & 1.2 & 2.2 \\
\hline March 4 & $0919: 23.83$ & 15 & 12.35 & 104 & 47.19 & 3.35 & 18 & 3 & 144 & 8.5 & 0.15 & 0.6 & 1.1 \\
\hline March 4 & $0937: 47.56$ & 15 & 12.73 & 104 & 48.75 & 11.99 & 4 & 1 & 216 & 11.3 & 0.11 & 1.0 & pdc \\
\hline March 4 & $0942: 18.27$ & 15 & 12.49 & 104 & 47.32 & 7.80 & 19 & 1 & 144 & 8.5 & 0.14 & 0.6 & 2.0 \\
\hline March 4 & $1001: 7.85$ & 15 & 12.00 & 104 & 47.27 & 6.16 & 4 & 1 & 226 & 14.0 & 0.13 & 1.1 & pdc \\
\hline March 4 & $1012: 53.66$ & 15 & 12.48 & 104 & 47.83 & 8.19 & 4 & 1 & 223 & 13.0 & 0.12 & 1.1 & pdc \\
\hline March 4 & $1037: 12.09$ & 15 & 9.50 & 104 & 50.83 & 5.77 & 4 & 0 & 199 & 0.8 & 0.00 & 1.4 & 0.7 \\
\hline March 4 & $1053: 8.26$ & 15 & 9.47 & 104 & 49.79 & 11.64 & 4 & 1 & 204 & 9.9 & 0.05 & 1.5 & pdc \\
\hline March 4 & $1121: 17.06$ & 15 & 25.62 & 104 & 59.15 & 0.46 & 8 & 0 & 174 & 4.6 & 0.11 & 1.1 & 3.7 \\
\hline March 4 & $1459: 45.84$ & 15 & 18.92 & 104 & 45.95 & 1.84 & 7 & 1 & 233 & 18.1 & 0.08 & 0.8 & 1.7 \\
\hline March 4 & $1856: 5.16$ & 15 & 25.24 & 105 & 0.22 & 2.55 & 15 & 2 & 163 & 6.4 & 0.10 & 1.0 & 13 \\
\hline March 4 & $2010: 37.27$ & 15 & 23.80 & 105 & 12.44 & 15.04 & 8 & 1 & 135 & 15.0 & 0.07 & 0.6 & 1.6 \\
\hline March 5 & $0058: 14.75$ & 15 & 44.28 & 104 & 44.18 & 18.18 & 6 & 0 & 297 & 41.4 & 0.15 & 3.6 & 6.5 \\
\hline March 5 & $0219: 4.28$ & 15 & 13.08 & 104 & 47.88 & 8.82 & 9 & 2 & 145 & 12.9 & 0.10 & 0.6 & 2.1 \\
\hline March 5 & $1010: 27.31$ & 15 & 18.58 & 104 & 44.46 & 17.21 & 9 & 1 & 192 & 20.2 & 0.10 & 0.9 & 3.6 \\
\hline March 6 & $2305: 13.10$ & 15 & 23.65 & 105 & 0.51 & 8.13 & 3 & 1 & 356 & 4.5 & 0.09 & 2.7 & pdc \\
\hline March 7 & $1643: 31.65$ & 15 & 26.55 & 105 & 12.41 & 0.78 & 8 & 1 & 259 & 20.6 & 0.07 & 1.9 & 2.7 \\
\hline March 8 & $0002: 35.97$ & 15 & 13.05 & 104 & 47.67 & 8.81 & 6 & 1 & 145 & 8.9 & 0.09 & 0.6 & 2.7 \\
\hline March 8 & $0023: 55.33$ & 15 & 12.87 & 104 & 48.46 & 0.08 & 4 & 1 & 178 & 7.8 & 0.14 & 2.6 & 2.8 \\
\hline March 8 & $0058: 5.39$ & 15 & 13.33 & 104 & 47.23 & 4.17 & 14 & 2 & 149 & 9.8 & 0.14 & 0.6 & 1.5 \\
\hline March 8 & $0131: 55.08$ & 15 & 13.81 & 104 & 47.54 & 0.12 & 4 & 1 & 151 & 16.3 & 0.03 & 0.4 & 1.2 \\
\hline March 8 & $1214: 26.42$ & 15 & 24.06 & 105 & 7.06 & 0.00 & 18 & 1 & 88 & 10.1 & 0.08 & 0.3 & 1.0 \\
\hline March 8 & $1219: 0.53$ & 15 & 24.04 & 105 & 6.43 & 0.11 & 16 & 2 & 82 & 9.0 & 0.11 & 0.4 & 1.0 \\
\hline March 8 & $1238: 22.63$ & 15 & 24.06 & 105 & 6.90 & 0.30 & 16 & 3 & 147 & 9.0 & 0.12 & 0.4 & 1.0 \\
\hline March 8 & $1250: 17.03$ & 15 & 25.63 & 105 & 7.41 & 8.56 & 4 & 1 & 187 & 8.3 & 0.03 & 1.0 & 2.9 \\
\hline March 8 & $1258: 1.94$ & 15 & 6.30 & 104 & 45.38 & 0.93 & 3 & 1 & 286 & 18.6 & 0.18 & 1.8 & 5.3 \\
\hline March 8 & $1339: 26.56$ & 15 & 23.87 & 105 & 6.08 & 0.18 & 6 & 0 & 86 & 8.4 & 0.10 & 0.5 & pdc \\
\hline March 8 & $1432: 18.41$ & 15 & 24.49 & 105 & 5.32 & 0.06 & 7 & 0 & 83 & 7.8 & 0.13 & 0.9 & 6.9 \\
\hline March 8 & $1445: 54.67$ & 15 & 24.31 & 105 & 5.50 & 0.79 & 6 & 0 & 87 & 7.9 & 0.03 & 0.6 & 3.4 \\
\hline March 8 & $1451: 59.77$ & 15 & 24.02 & 105 & 6.29 & 0.22 & 7 & 0 & 91 & 8.8 & 0.10 & 0.7 & 5.6 \\
\hline March 8 & $1452: 16.69$ & 15 & 24.58 & 105 & 6.60 & 1.41 & 10 & 1 & 207 & 30.6 & 0.09 & 0.9 & 2.1 \\
\hline March 8 & $1514: 9.56$ & 15 & 24.38 & 105 & 5.43 & 0.37 & 4 & 1 & 161 & 7.9 & 0.10 & 0.7 & 2.0 \\
\hline March 8 & $1601: 29.79$ & 15 & 24.46 & 105 & 5.88 & 0.06 & 16 & 0 & 79 & 8.6 & 0.12 & 0.4 & 1.3 \\
\hline March 8 & $1832: 44.68$ & 15 & 16.64 & 104 & 31.57 & 5.01 & 7 & 0 & 276 & 36.2 & 0.09 & 4.0 & pdc \\
\hline March 8 & $2044: 39.14$ & 15 & 25.04 & 105 & 16.43 & 2.00 & 6 & 1 & 239 & 26.6 & 0.07 & 1.4 & pdc \\
\hline March 12 & $1101: 54.18$ & 15 & 11.53 & 104 & 45.88 & 4.46 & 13 & 1 & 211 & 12.5 & 0.08 & 0.6 & 1.0 \\
\hline March 13 & $1849: 17.42$ & 15 & 8.81 & 104 & 39.07 & 4.15 & 6 & 1 & 295 & 14.8 & 0.03 & 1.0 & 1.3 \\
\hline March 13 & $2342: 10.64$ & 15 & 9.07 & 104 & 48.09 & 16.15 & 5 & 0 & 229 & 20.0 & 0.14 & 2.4 & 7.1 \\
\hline March 14 & $1107: 53.31$ & 15 & 51.83 & 104 & 7.25 & 14.93 & 5 & 0 & 329 & 111.4 & 0.22 & 3.4 & pdc \\
\hline
\end{tabular}

Latitudes and longitudes are in degrees and minutes $\mathrm{N}$ and $\mathrm{W}$, respectively; nor, number of readings; mag, maximum azimuthal gap; dcs, distance to closest station; rmsr, root mean square residual; erh, horizontal error (from projection of error ellipse onto horizontal plane); erd, depth error; pcd, poor depth control (as indicated by an eigenvalue of $[A]$ less than 0.016 , corresponding primarily to the hypocentral adjustment in depth); the error ellipses are at $32 \%$ confidence.

waii, and Texas instruments for the events from this northern area are consistent with right lateral strike slip motion along faults parallel to the trough.

The second concentration of microearthquake activity is southeast of the first and is associated with two topographic troughs, one trending approximately east-west and the other trending north-south. The distribution of epicenters displays a broad north-south trend. Most of the events were clustered at the intersection of the two troughs. The southern, deepest part of the north-south trending trough did not manifest any seis- mic activity during the experiment. Several of the events from this area do not bear any obvious relationship to the topography (e.g., March 2, 0523 hours; March 5, 1010 hours). The depths indicated for these earthquakes are quite scattered and some events may have been subcrustal. One event in particular (March 2, 0523 hours) was recorded throughout the array and consistently yields an apparently well constrained depth of about $12 \mathrm{~km}$ below seafloor. The first-motion radiation patterns from the largest of these events do not permit a simple determination of the source mechanism, at least not with the 


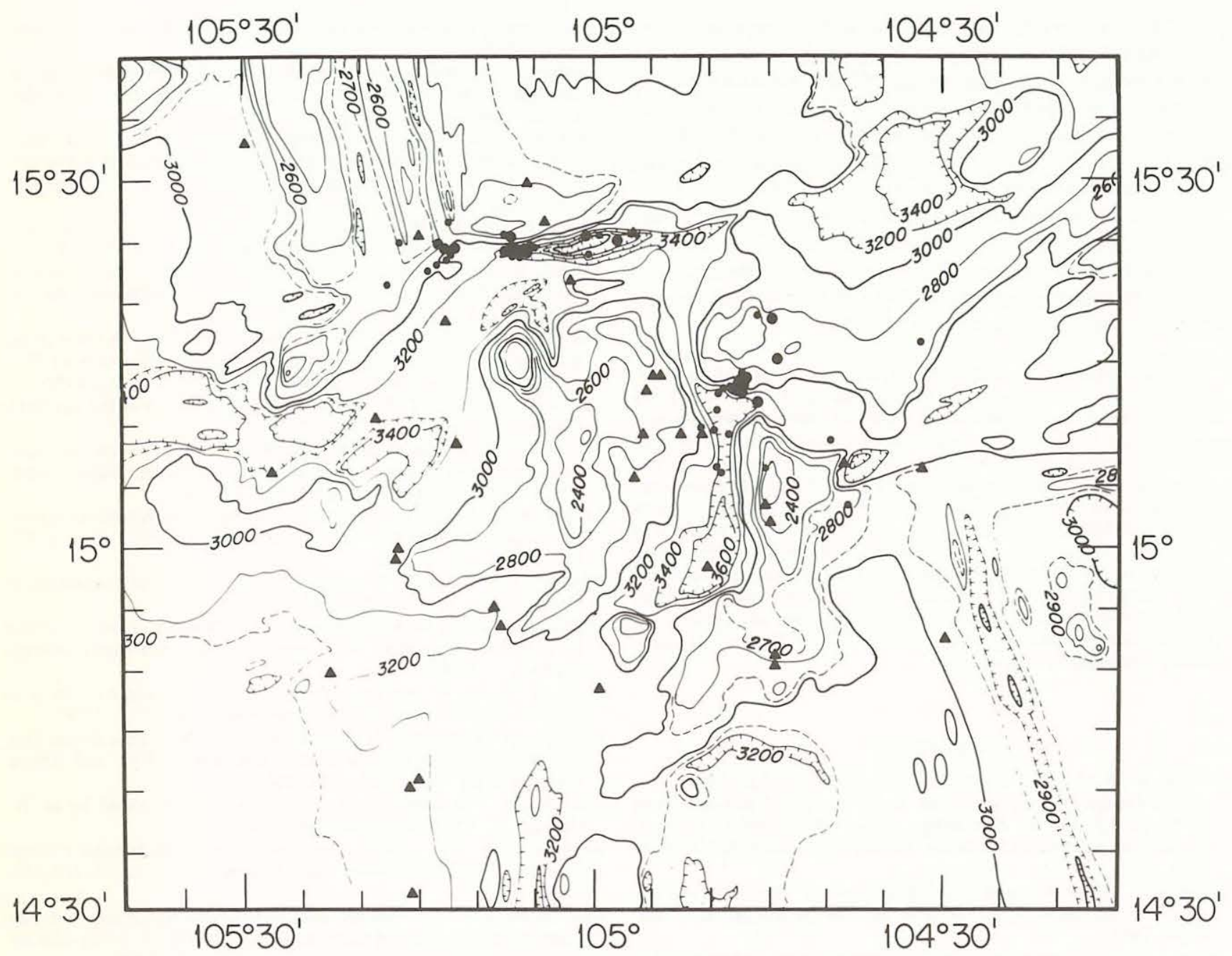

Fig. 3. Stations (triangles) and earthquakes (large dots represent events located using at least 10 readings, small dots represent events located using fewer than 10 readings) from phase II of ROSE superimposed on the local bathymetry of the active portion of the Orozco Fracture Zone. Geographical coordinates of the instruments are listed in Table 1, and hypocentral parameters of the earthquakes are given in Table 3 . The bathymetric map is a preliminary map constructed by $\mathrm{J}$. Mammerickx including data obtained by the R/V Conrad and R/V Kana Keoki during phase II of ROSE. Contours are in corrected meters; the contour interval is $100 \mathrm{~m}$. The axis of the East Pacific Rise to the north and south of the fracture zone is at longitudes of $105^{\circ} 20^{\prime}$ and $104^{\circ} 20^{\prime}$, respectively. The main shock-aftershock sequence of March 8 was located at approximately $15^{\circ} 24^{\prime} \mathrm{N}, 105^{\circ} 06^{\prime} \mathrm{W}$.

data currently available. They do not, however, appear to be consistent with simple strike-slip motion.

Of the events for which arrival times are presently available from four or more instruments, only two (March 5, 0058 hours; March 14, 1107 hours) seem to have been outside of the active transform zone. Because these two events occurred well outside of the station network, errors on the hypocentral coordinates are probably larger than those listed in Table 3, and we cannot say whether or not these events were associated with the Orozco Fracture Zone. Station T14, located near the axis of the East Pacific Rise, recorded many near earthquakes (with $S$ - $P$ times less than $2 \mathrm{~s}$ ), but none of these events were large enough to have been located by the network.

\section{CONCLUSIONS}

1. Project ROSE has yielded a data set on oceanic microearthquakes unique in the number of independent recordings of the larger events and in the extent to which epicentral locations, focal depth, and other source parameters may be quan- titatively characterized. The experiment has also demonstrated the power of redundancy in an OBS and OBH network.

2. In the Orozco Fracture Zone during the period February 27 to March 14, 1979, some 50 microearthquakes were recorded by enough stations in the ROSE network to determine preliminary hypocentral locations and origin times. Of the well-located epicenters, all lie within the active portion of the Orozco transform fault.

3. Roughly one-half of the earthquakes were aligned along a long narrow trough that extends at $\mathrm{N} 80^{\circ} \mathrm{E}$ azimuth from the northern rise crest intersection. The strike of the trough and first motions from these events support the hypothesis that these earthquakes occurred by strike-slip faulting with slip in the direction of relative motion of the Cocos and Pacific plates. Well-constrained focal depths for these events range from very shallow to subcrustal; the nominal depth range is 0 to $17 \mathrm{~km}$.

4. Most of the remaining earthquakes occurred in a topographically complicated region in the central transform, an 
area that may owe its complexity to one or more spreading pole changes and ridge jumps in this part of the Pacific in the last few million years. While some of these events are closely associated with topographic features, others are not, and there is no clear lineation of epicenters in the direction of predicted plate motion. Well-constrained focal depths for this second group of earthquakes also range from 0 to $17 \mathrm{~km}$.

5. The preliminary hypocentral locations of Orozco fracture zone microearthquakes reported here will form the basis for further, more detailed studies by ROSE investigators of earthquake source properties and of the propagation characteristics of earthquake-generated phases.

Acknowledgments. We thank the captains and crews of the R/V Conrad, R/V Kana Keoki, R/V Thomas Thompson, and USNS De Steiguer and the other scientists and technical personnel who participated in phase II of ROSE. We also thank J. Mammerickx for providing the bathymetric map used in Figure 3. Financial support for this experiment was provided by the Office of Naval Research, under contract N00014-80-C-0273 to MIT, N00014-79-C-0071 and NR-083-004 to WHOI, N00014-78-C-0570 to the University of Texas, NRO7-456 to the University of Calif. at Santa Barbara, N00014-80-C-0252 to the University of Washington, N00014-79-C-0004 to Oregon State University, N00014-80-C-0098 to Lamont-Doherty Geological Observatory, N00014-75-C-0209 to the University of Hawaii, and by the National Science Foundation, under grant EAR78-23849 to LamontDoherty Geological Observatory.

\section{REFERENCES}

Bookbinder, R. G., A. C. Hubbard, W. G. MacDonald, and P. W. Pomeroy, Design of an ocean bottom seismometer with response from $25 \mathrm{~Hz}$ to $100 \mathrm{sec}$, in Proceedings of the 4th Annual Conference: Oceans 78, pp. 510-515, Marine Technology Society/IEEE, New York, 1978 .

Chase, T. E., H. W. Menard, and J. Mammerickx, Bathymetry of the north Pacific, maps 9, 10, Scripps Inst. of Oceanogr., La Jolla, Calif., 1969.

Ewing, J. I., RosE project overview and general results (abstract), Eos Trans. $A G U, 60,887,1979$.

Francis, T. J. G., and I. T. Porter, Median valley seismology: The mid-Atlantic ridge near $45^{\circ} \mathrm{N}$, Geophys. J. R. Astron. Soc., 34, 279$311,1973$.

Francis, T. J. G., I. T. Porter, and J. R. McGrath, Ocean-bottom seismograph observations on the mid-Atlantic ridge near lat. $37^{\circ} \mathrm{N}$, Geol. Soc. Amer. Bull., 88, 664-677, 1977.

Francis, T. J. G., I. T. Porter, and R. C. Lilwall, Microearthquakes near the eastern end of St. Paul's Fracture Zone, Geophys. J. R. Astron. Soc., 53, 201-217, 1978.

Johnson, R. V., II, C. R. B. Lister, and B. T. R. Lewis, A direct recording ocean bottom seismometer, Mar. Geophys. Res., 3, 65-85, 1977.

Johnson, S. H., and P. R. Jones, Microearthquakes located on the Blanco fracture zone with sonobuoy arrays, J. Geophys. Res., 83, 255-261, 1978.

Johnson, S. H., M. D. Cranford, B. T. Brown, J. E. Bowers, and R. E. McAllister, A free-fall direct recording ocean bottom seismograph, Mar. Geophys. Res., 3, 103-117, 1977.

Jones, P. R., and S. H. Johnson, Sonobuoy array measurements of active faulting on the Gorda ridge, J. Geophys. Res., 83, 3435-3440, 1978.

Klein, F. W., Hypocenter location program HYPOINVERSE, 1, User's guide to versions 1, 2, 3, 4, Geol. Surv. Open File Rep. U.S., 78-694, 1978.

Klitgord, K. D., and J. Mammerickx, Bathymetric, magnetic and tec- tonic trends of the East Pacific Rise, $8^{\circ}-21^{\circ} \mathrm{N}$ (abstract), Eos Trans. $A G U, 60,888,1979$.

Koelsch, D. E., and G. M. Purdy, An ocean bottom hydrophone instrument for seismic refraction experiments in the deep ocean, Mar. Geophys. Res., 4, 115-125, 1979.

Latham, G., P. Donoho, K. Griffiths, A. Roberts, and A. K. Ibrahim, The Texas ocean bottom seismograph, paper presented at the Offshore Technology Conference, Soc. of Explor. Geophys., Houston, Tex., 1978.

Lewis, B. T. R., and W. E. Snydsman, Fine structure of the lower oceanic crust on the Cocos plate, Tectonophysics, 55, 87-105, 1979.

Lilwall, R. C., T. J. G. Francis, and I. T. Porter, Ocean-bottom seismograph observations on the mid-Atlantic ridge near $45^{\circ} \mathrm{N}$, Geophys. J. R. Astron. Soc., 51, 357-370, 1977.

Lilwall, R. C., T. J. G. Francis, and I. T. Porter, Ocean-bottom seismograph observations on the mid-Atlantic ridge near $45^{\circ} \mathrm{N}-$ Further results, Geophys. J. R. Astron. Soc., 55, 255-262, 1978.

Lynn, W. S., and B. T. R. Lewis, Tectonic evolution of the northern Cocos plate, Geology, 4, 718-722, 1976.

Macdonald, K. C., and J. D. Mudie, Microearthquakes on the Galapagos spreading center and the seismicity of fast-spreading ridges, Geophys. J. R. Astron. Soc., 36, 245-257, 1974.

Mattaboni, P. J., and S. C. Solomon, MiTOBS: A seismometer system for ocean-bottom earthquake studies, Mar. Geophys. Res., 3, 87 102, 1977.

Minster, J. B., and T. H. Jordan, Present-day plate motions, $J$. Geophys. Res., 83, 5331-5354, 1978.

Orcutt, J. A., B. L. N. Kennett, and L. M. Dorman, Structure of the East Pacific Rise from an ocean bottom seismometer survey, Geophys. J. R. Astron. Soc., 45, 305-320, 1976.

Prothero, W. A., Jr., An operationally optimized ocean-bottom seismometer capsule, Phys. Earth Planet. Inter., 18, 71-77, 1979.

Prothero, W. A., I. Reid, M. S. Reichle, and J. N. Brune, Ocean bottom seismic measurements on the East Pacific Rise and Rivera Fracture Zone, Nature, 262, 121-124, 1976.

Raitt, R. W., The crustal rocks, in The Sea, vol. 3, edited by M. N. Hill, pp. 85-102, Interscience, New York, 1963.

Reichle, M. S., and I. Reid, Detailed study of earthquake swarms from the Gulf of California, Bull. Seismol. Soc. Am., 67, 159-171, 1977.

Reichle, M. S., G. F. Sharman, and J. N. Brune, Sonobuoy and teleseismic study of Gulf of California transform fault earthquake sequences, Bull. Seismol. Soc. Am., 66, 1623-1641, 1976.

Reid, I., and K. Macdonald, Microearthquake study of the mid-Atlantic ridge near $37^{\circ} \mathrm{N}$, using sonobuoys, Nature, 246, 88-89, 1973.

Reid, I., M. Reichle, J. Brune, and H. Bradner, Microearthquake studies using sonobuoys, preliminary results from the Gulf of California, Geophys. J. R. Astron. Soc., 34, 365-379, 1973.

Reid, I., J. A. Orcutt, and W. A. Prothero, Seismic evidence for a narrow zone of partial melting underlying the East Pacific rise at $21^{\circ} \mathrm{N}$, Geol. Soc. Am. Bull., 88, 678-682, 1977.

Sclater, J. G., R. N. Anderson, and M. L. Bell, Elevation of ridges and evolution of the central eastern Pacific, J. Geophys. Res., 76, 7888$7914,1971$.

Solomon, S. C., P. J. Mattaboni, and R. L. Hester, Microseismicity near the Indian Ocean triple junction, Geophys. Res. Lett., 4, 597600, 1977.

Spindel, R. C., S. B. Davis, K. C. Macdonald, R. P. Porter, and J. D. Phillips, Microearthquake survey of median valley of the mid-Atlantic ridge at $36^{\circ} 30^{\prime} \mathrm{N}$, Nature, 248, 577-579, 1974.

Sutton, G. H., J. Kasahhara, W. N. Ichinose, and D. A. Byrne, Ocean bottom seismograph development at Hawaii Institute of Geophysics, Mar. Geophys. Res., 3, 153-177, 1977.

Wilson, J. T., A new class of faults and their bearing on continental drift, Nature, 207, 343-347, 1965.

(Received June 13, 1980; revised October 27, 1980; accepted October 30, 1980.) 
MANDATORY DISTRIBUTION LIST

FOR UNCLASSIFIED TECHNICAL REPORTS, REPRINTS, AND FINAL REPORTS PUBLISHED BY OCEANOGRAPHIC CONTRACTORS

OF THE OCEAN SCIENCE AND TECHNOLOGY DIVISION

OF THE OFFICE OF NAVAL RESEARCH

(REVISED NOVEMBER 1978)

1 Deputy Under Secretary of Defense

(Research and Advanced Technology)

Military Assistant for Environmental Science

Room 3D129

Washington, D.C. 20301

Office of Naval Research

800 North Quincy Street

Arlington, VA 22217

3 ATTN: Code 483

1 ATTN: Code 460

2 ATTN: 102B

1 CDR Joe Spigai, (USN)

ONR Representative

Woods Hole Oceanographic Inst.

Woods Hole, MA 02543

Commanding Officer

Naval Research Laboratory

Washington, D.C. 20375

6 ATTN: Library, Code 2627

12 Defense Technical Information Center

Cameron Station

Alexandria, VA 22314

ATTN: DCA

Commander

Naval Oceanographic Office

NSTL Station

Bay St. Louis, MS 39522

1 ATTN: Code 8100

1 ATTN: Code 6000

1 ATTN: Code 3300

1 NODC/NOAA

Code D781

Wiscons in Avenue, N.W.

Washington, D.C. 20235

1 Mr. Michael H. Kelly

Administrative Contracting Officer

Department of the Navy

Office of Naval Research

Eastern/Central Regional Office

Building 114, Section D

666 Summer Street

Boston, MA 02210 


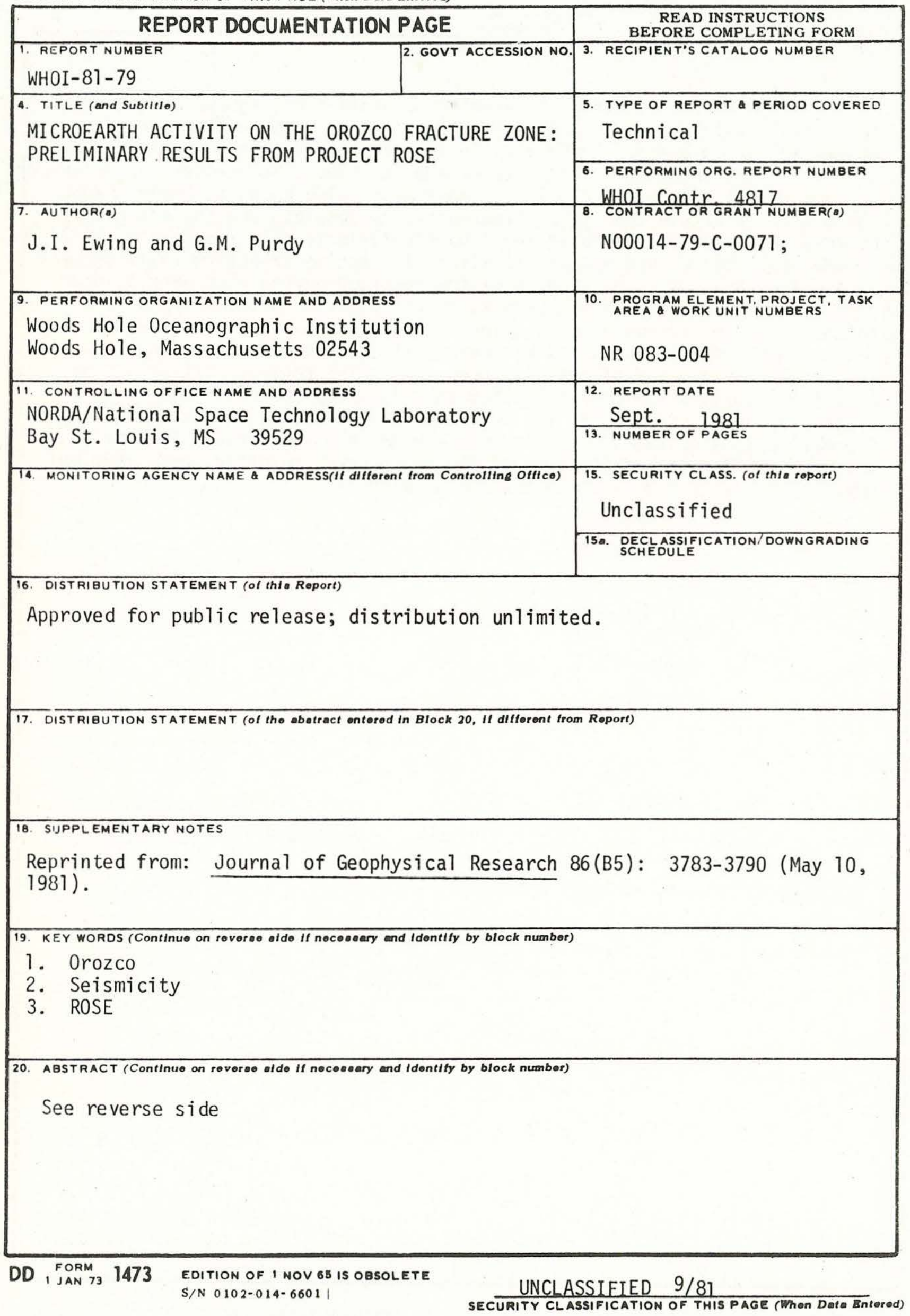


20.

We present preliminary hypocenter determinations for 52 earthquakes recorded by a large multi-institutional network of ocean bottom seismometers and ocean bottom hydrophones in the Orozco Fracture Zone in the eastern Pacific during late February to mid-March 1979. The network was deployed as part of the Rivera Ocean Seismic Experiment, also known as Project ROSE. The Orozcc Fracture Zone is physiographically complex, and the pattern of microearthquake hypocenters at least partly reflects this complexity. All of the we11-located epicenters lie within the active transform fault segment of the fracture zone. About half of the recorded earthquakes were aligned along a narrow trough that extends eastward from the northern rise crest intersection in the approximate direction of the Cocos-Pacific relative plate motion; these events appear to be characterized by strike-slip faulting. The second major group of activity occurred in the central portion of the transform fault; the microearthquakes in this group do not display a preferred alignment parallel to the direction of spreading, and several are not obviously asoociated with distinct topographic features. Hypocentral depth was well resolved for many of the earthquakes reported here. Nominal depths range from 0 to $17 \mathrm{~km}$ below the seafloor. 


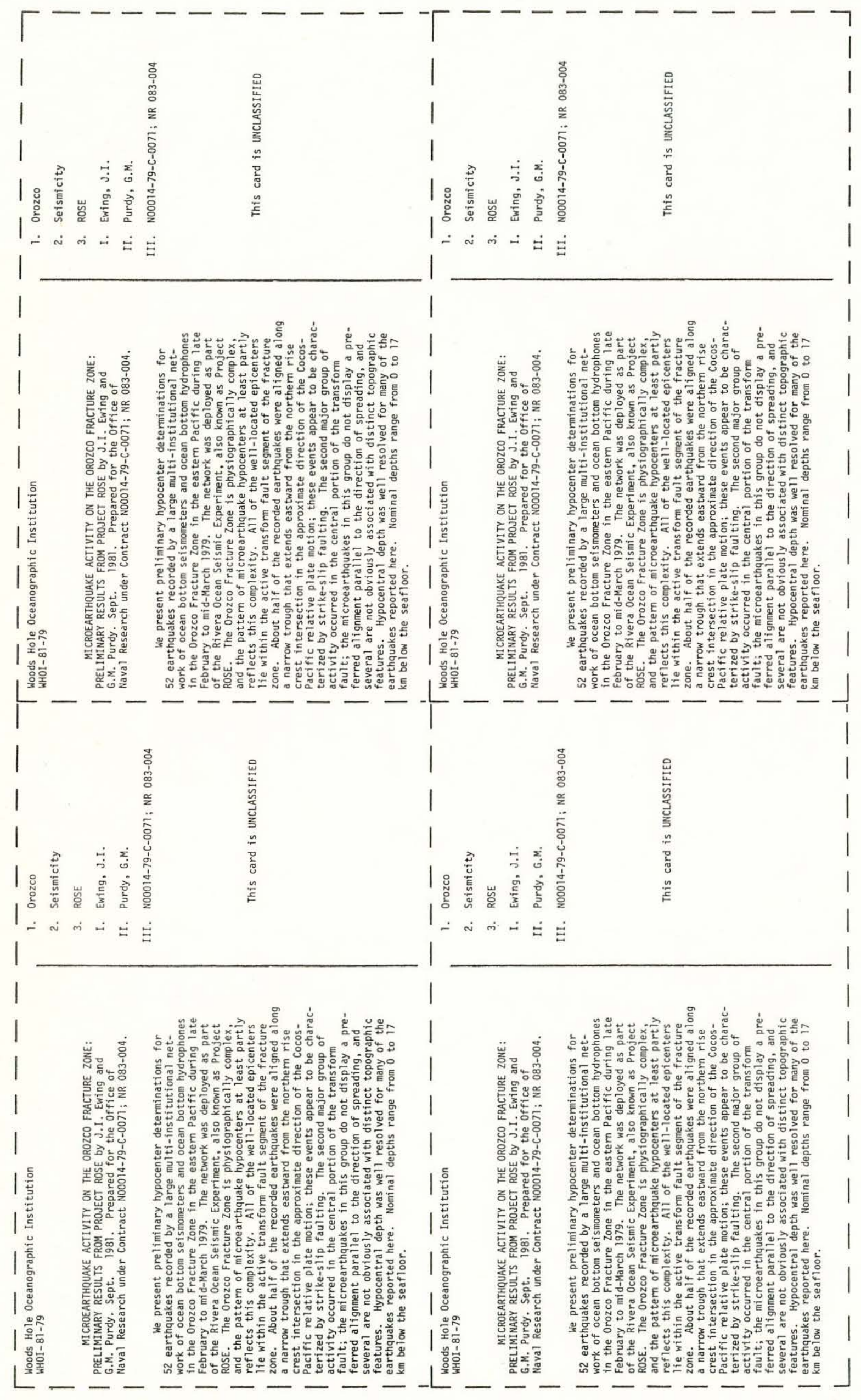

